\title{
FOOD, ART AND PHILOSOPHY
}

Paloma Atencia Linares Universidad Nacional de Educación a Distancia (UNED) Dpto. Lógica, Historia y Filosofía de la Ciencia patencia@fsof.uned.es

AARON MESKIN

University of Georgia Department of Philosophy Aaron.Meskin@uga.edu

The philosophy of food is an emerging and distinctive area of philosophical inquiry, and much of the work in this area has been informed by philosophical aesthetics. In recent years, philosophers have found it especially productive to explore connections between aesthetics and the sciences and philosophy of the mind. This special issue of Crítica, Revista Hispanoamericana de Filosofía aims to bring together these two developments to explore what can be learned about food by approaching it from philosophical perspectives that are richly informed by our best aesthetic theories and our best theories of the mind.

In this introduction, we contextualize the recent development of the philosophy of food as an autonomous subdiscipline within philosophy and situate the essays in the special issue in relation to that subdiscipline.

Traditional Neglect of Food in Philosophy and the Rise of the Philosophy of Food

Food has traditionally been a neglected topic in philosophy. This doesn't mean that philosophers have never talked about food. Within the Western tradition, the one we focus on in this special issue, one can find discussions of food, drink and the consumption of both in philosophical writings from ancient Greece (Plato and Aristotle), the medieval era (Augustine), modern philosophy (Locke and Rousseau), and the nineteenth century (Nietzsche).

The essay in this volume by Sofía Ortiz-Hinojosa and Sergio Armando Gallegos Ordorica, "Arte culinario y creación poética en Sor 
Juana Inés de la Cruz", provides another example of early philosophical attention to food, in this case by the groundbreaking Novohispanic philosopher Sor Juana Inés de la Cruz. We return to this essay below.

Given these, and other, examples of philosophical discussions of food, what do we mean by talking about the philosophical neglect of food? We mean to indicate three things.

First, there is a disproportionate neglect of food in philosophy. Despite the significance of food to human life for survival and wellbeing, and its prominence in other fields such as history or anthropology, it is striking that philosophical discussion of food has been quite limited and certainly much more minimal than the discussion of, say, beauty and art.

Second, despite the existence of some philosophical discussions of food, it cannot be said that there has been, at least until recently, a clear and distinct domain of the philosophy of food. The discussion of food by philosophers, even in the context of their philosophical research, does not, on its own, entail the existence of a distinct subdiscipline devoted to the philosophy of food, for the latter requires that there be something like a coherent tradition of inquiry, a set of structuring questions or topics and, perhaps, some sort of institutional recognition. And those, we suggest, do not clearly emerge until quite recently.

Philosophical aesthetics is a useful comparison here. Philosophers have discussed beauty and the arts since Plato's time. But it is commonly said that aesthetics as a distinct subdiscipline of philosophy does not appear until the eighteenth century with the work of Shaftesbury, Batteux, Baumgarten, Hutcheson, Hume and others (Kristeller 1951, p. 496; Guyer 2003, p. 25; Walton 2007, p. 147). Something similar, we suggest, is true about the philosophy of food in the twentieth century.

Of course, one might point out that not every significant - and robustly developed - topic in philosophy marks out a distinct subdiscipline: beauty and justification are cases in point. There's no separate domain of the philosophy of beauty or the philosophy of justification, but these are topics that are taken seriously and widely discussed in different philosophical areas such as aesthetics and epistemology respectively. But this leads us to our third point about food's neglect. The problem is not only that there was, at least until recently, no distinct subdiscipline of the philosophy of food, but that food, even when it appears in philosophical texts, was traditionally 
not taken very seriously. Knowledge and justification have always been considered serious philosophical concerns since ancient times, but food and cookery have not. Plato, for instance, suggests that cooking, very much like rhetoric, aims at mere flattery and is based on apparent knowledge (Gorgias 465a-d; Snell 1982). The association of food with bodily — as opposed to intellectual - pleasures, and the prevalence in traditional philosophy of views which ranked the mind as more important than the body, probably contributed to the historical disregard of food as a legitimate philosophical topic of inquiry.

Notice that the case of beauty and the arts provides an interesting contrasting example. Beauty, like knowledge and justification and unlike food, has always been a serious philosophical subject matter - although, we might suspect that its frequent association with truth or the moral good might have partly facilitated its philosophical reputation. The arts, on the other hand, while they were discussed in philosophical texts, were considered to be of more of technical than intellectual interest. It was not until the eighteenth century that philosophers began the long project of disentangling beauty from morality, and it became a central topic of inquiry; also, the arts acquired, for some contingent historical facts, sufficient social relevance and pedigree that philosophical aesthetics was vindicated as an autonomous area of inquiry worthy of philosophical attention. Hence, the twentieth century might have been for food in philosophy what the eighteenth century represented for aesthetics.

Now, why wasn't the philosophical study of food and bodily taste simply a part of the tradition of philosophical aesthetics since its foundation in the eighteenth century? After all, pleasure, taste, judgment and perception are core concerns within philosophical aesthetics, and these are also central to the philosophical concern with food and eating. The answer to this is complex, but a key factor is that traditional aesthetics was very much influenced by ideas that were prominent in the eighteenth century and particularly Kant's sharp distinction between the beautiful - a pleasure that involves the cognitive faculties - and the agreeable - a lower and purely sensorial pleasure, which included the pleasure derived from food. Aestheticians from the nineteenth century onwards tended to focus on the former rather than the latter. Crucially, modern aestheticians emphasized and popularized the putative distinction between (the beautiful) arts and crafts or popular arts (what Kant called "the agreeable arts") (Collingwood 1938; Kant 1790) which further contributed to relegating food and cookery from the field of aesthetics. Other relevant fac- 
tors include gendered attitudes towards food and eating (Korsmeyer 2004) and corresponding gender biases within philosophy, as well as a philosophical tendency to privilege certain senses (vision and hearing) while denigrating those most relevant to food (viz., taste and smell) (Korsmeyer 1999).

We argue, then, that despite earlier discussions of food by philosophers, the philosophy of food does not come into its own as a distinct subdiscipline of philosophy within the broadly analytic tradition until the 1990s with the publication of Elizabeth Telfer's Food for Thought: Philosophy and Food in 1996 and Carolyn Korsmeyer's Making Sense of Taste: Food and Philosophy in 1999. Deane Curtin and Lisa Heldke's 1992 anthology, Cooking, Eating, Thinking: Transformative Philosophies of Food, is also important to consider in this context, although it is largely composed of previously published work.

Since then, there have been many other book-length treatments of the topic. These include Heldke's Exotic Appetites: Ruminations of a Food Adventurer in 2003; Julian Baggini's 2013 The Virtues of the Table: How to Eat and Think; Raymond D. Boisvert and Heldke's co-authored 2016 volume entitled Philosophers at Table: On Food and Being Human; Nicola Perullo's Taste as Experience: The Philosophy and Aesthetics of Food also in 2016; and Kevin Sweeney's 2018 monograph, The Aesthetics of Food: The Philosophical Debate about What We Eat and Drink.

Key anthologies of new work published in the last few decades include Fritz Allhoff and Dave Monroe's Food and Philosophy: Eat Think and Be Merry in 2007, and David Kaplan's The Philosophy of Food in 2012.

A further sign of the development of the field is the publication of textbooks designed for teaching the philosophy of food at an undergraduate level, notably Alexandra Plakias' Thinking Through Food: A Philosophical Introduction in 2019, and Kaplan's Food Philosophy: An Introduction in 2020.

Alongside this work on food in general, there has been a flurry of work published on the philosophy of wine: Barry Smith's edited 2007 collection Questions of Taste: The Philosophy of Wine; Douglas Burnham and Ole M. Skilleas's The Aesthetics of Wine in 2012; a special issue of Revisita di estitica devoted to wine in 2012; Roger Scruton's I Drink Therefore I Am: A Philosopher's Guide to Wine in 2013; and Cain Todd's A Philosophy of Wine: A Case of Truth, Beauty and Intoxication in 2014. 
And, of course, there is work on food ethics. That work largely falls outside of our focus in this special issue, but it is well-represented in many of the works mentioned above and is the focus of important recent works such as Peter Singer and Jim Mason's 2007 The Ethics of What We Eat: Why Our Food Choices Matter; 2015's The Moral Complexities of Eating Meat edited by Ben Bramble and Bob Fischer; and The Oxford Handbook of Food Ethics, published in 2018. Of course, philosophical attention to ethical issues surrounding food appeared earlier -in Peter Singer's 1975 Animal Liberation, for example. We think that much of that earlier work in food ethics is best seen as falling into the category of applied ethics rather than the philosophy of food, but it very plausibly contributed to paving the way for the emergence of a new discipline.

It's also worth noting that this is the fourth special issue of a journal devoted to the philosophy of food in the last few years! The Monist published a special issue devoted to food in 2018. Argumenta, the journal of the Italian Society for Analytic Philosophy, published an entire issue devoted to metaphysical issues raised by food and its consumption in 2020. Also in 2020, Humana.Mente published a special issue on the philosophy of food with a particular focus on recipes. In this volume, we focus on the philosophy of food as it relates to aesthetics and the arts.

\section{Philosophy of Food, Aesthetics and Art}

Recent development in philosophical aesthetics, especially everyday aesthetics and feminist aesthetics, as well as the development of nonKantian accounts of aesthetic experience and a serious consideration of the popular arts, have meant that the subdiscipline has been especially welcome in recent years to discussion of food.

In this spirit, Sofía Ortiz-Hinojosa and Sergio Armando Gallegos Ordorica, whose paper we mentioned above, vindicate the figure of the neglected but important Baroque female Mexican poet, cook and philosopher, Sor Juana Inés de Cruz, as an example of an author in the history of philosophy who not only took food practice seriously as a topic of intellectual inquiry but whose work is systematically influenced by her culinary practices. Ortiz-Hinojosa and Gallegos Ordorica explore interesting and systematic relations between poetic creation and culinary art in the writings of Sor Juana Inés de la Cruz. They claim that culinary art plays significant roles in her work, including functioning as a distinctive, multi-layered enabling 
condition for poetic creation that transforms the understanding of the notions of taste, love, and the desire for the moral good.

We believe that the recent emergence (or, more accurately, reemergence) of empirically-informed or "naturalized" aesthetics (Smith 2017) is another significant factor that has made the field more hospitable to the study of food. These scientifically-informed approaches, which focus the role of our affective, cognitive and perceptual capacities in the experience of art and other aesthetic objects, are especially well-suited to avoiding the sorts of cultural prejudices sketched in the previous paragraph.

The central questions about food that have concerned philosophical aestheticians have had to do with food's status as art and as a source of aesthetic experience (Telfer 1996; Korsmeyer 1999). A number of essays in this volume focus on those questions.

In her essay, "Meals, Art and Meaning", Eileen John defends and extends the arguments of an earlier paper (John 2014) where she argued that meals could not be art. The essay in this issue, strongly influenced by anthropological work on food, focuses on the different ways in which works of art and meals bear meaning. Meals differ from art in the way they connect subjective experience, meaning and appreciation. While it is essential to fully appreciate an artwork that the subject grasps the relevant meaning while experiencing the artwork, this is not the case for meals. Although meals can be meaningful, subjects do not need to grasp a specific meaning while experiencing the meal in order to fully appreciate it. Meals are not "well-governed intentional activities" with a pre-conceived coherent and unified meaning, and this is part of the kind of things they are and why we value these activities. This is why, if we want to turn meals into art, so to speak, there is a risk that we would be distorting the very identity of the practice and changing its value. Different meaning-practices such as those exemplified by art and meals are important for human life in different but complementary ways.

Mohan Matthen's essay, "Can Food be Art in Virtue of Its Savour Alone?", addresses food itself, rather than meals. In that essay, Matthen harnesses theories of aesthetic experience and art developed in earlier papers (Matthen 2015, 2017, 2020) to argue that food, even ordinary food, can be aesthetically, and ultimately artistically, appreciated for its "savour" - the food-related properties that we perceptually experience orally, alongside those perceived properties that are "naturally integrated" with the former. Food is aesthetically experienced and appreciated because we experience "facilitating pleasure" when we cognitively focus on its descriptive features (i.e., its 
savour). But the fact that we do this, and that food is often designed for this, is not enough to establish its status as art. What is crucial, on Matthen's account, is that some of the facilitating pleasures of food are culturally-learned. It is precisely when this facilitating pleasure is culturally constructed that we have art. And this, Matthen argues, provides a basis for thinking that ordinary and exceptional food can count as art; viz., in virtue of the culturally-situated aesthetic appreciation of savour.

Recent work in aesthetics on food and taste has gone beyond the questions of artistic status and aesthetic experience and addressed topics such as food and authenticity (Strohl 2019), the interaction of ethical and aesthetic values in food (Korsmeyer 2012), testimony about taste (Meskin and Robson 2015), food appreciation (Ravasio 2018), "terrible eating" (Korsmeyer 2002), and other topics. The essays by Shen-yi Liao and Uku Tooming in this issue continue the expansion of the philosophy of food.

Liao's essay, "Bittersweet Food", focuses on the connection between nostalgia and food. He develops a taxonomy of nostalgiainducing foods and then argues, on the basis of recent empirical theories of nostalgia, that the imagination plays a role in our experience of them. Applying the work of Kendall Walton, Liao argues that nostalgic foods are "props for games of make-believe"; that is, they are Waltonian fictions. Although this does not entail they are works of art, it does provide Liao with the resources for responding to Elizabeth Telfer's famous argument to the effect that food cannot be more than a minor art. Nostalgic food, Liao argues, can provide rich aesthetic experiences comparable to those provided by traditional major or "high" art forms.

Tooming's essay, "Aesthetics of Food Porn" focuses on oft-denigrated depictions of food that are designed to be arousing or exciting. Tooming argues that food porn is designed to arouse viewers' pleasure by encouraging them to engage in complex "constructive" acts of imagined tasting. Returning to an instance of the "food as art" issue described above, Tooming argues that the capacity for encouraging constructive imagining underwrites food porn's potential to count as an artistic achievement. ${ }^{1}$

${ }^{1}$ The Conference on Food, Art, and Philosophy, organized at the IIF, UNAM in October 2019, and which served as the basis for this special issue, would not have been possible without generous contributions from the American Society for Aesthetics, the Institute of Philosophical Research and Posgrado de Filosofia de Ciencia at UNAM, and the University of Georgia. We owe thanks to all of those organizations. Thanks also to all the conference participants and attendees for such 


\section{REFERENCES}

Collingwood, Robin G., 1938, The Principles of Art, Oxford University Press, London.

Guyer, Paul, 2003, "History of Modern Aesthetics", in Jerrold Levinson (ed.), The Oxford Handbook of Aesthetics, Oxford University Press, New York.

John, Eileen, 2014, "Meals, Art, and Artistic Value", Estetika: The Central European Journal of Aesthetics, vol. 51, no. 2, pp. 254-268.

Kant, Immanuel, 1790, Critique of Judgment, translated by J.H. Bernard, Hafner Publishing, New York, 1951. (Original publication date 1790.)

Korsmeyer, Carolyn, 2012, "Ethical Gourmandism", in David M. Kaplan (ed.), The Philosophy of Food, University of California Press, Berkeley, pp. 87-102.

——. 2004, Gender and Aesthetics, Routledge, New York.

—_, 2002, "Delightful, Delicious, Disgusting", The Journal of Aesthetics and Art Criticism, vol. 60, no. 3, pp. 217-225.

University Press, Ithaca.

Kristeller, Paul, 1951, "The Modern System of the Arts: A Study in the History of Aesthetics Part I", Journal of the History of Ideas, vol. 12, no. 4, pp. 496-527.

Matthen, Mohan, 2020, "Art Forms Emerging: An Approach to Evaluative Diversity in Art", The Journal of Aesthetics and Art Criticism, vol. 78, no. 3, pp. 303-318.

, 2017, "The Pleasure of Art", Australasian Philosophical Review, vol. 1, pp. 6-28.

— , 2015, "Play, Skill, and the Origins of Perceptual Art", British Journal of Aesthetics, vol. 55, no. 2, pp. 173-197.

Meskin, Aaron and Jon Robson, 2015, "Taste and Acquaintance", The Journal of Aesthetics and Art Criticism, vol. 73, no. 2, pp. 127-139.

Plato, 1998, Gorgias, translated with introduction, notes and interpretive essay by James H. Nichols, Cornell University Press, Ithaca, New York.

Ravasio, Matteo, 2018, "Food Landscapes: An Object-Centered Model of Food Appreciation", The Monist, vol. 101, no. 3, pp. 309-323.

Smith, Murray, 2017, Film, Art, and the Third Culture: A Naturalized Aesthetics of Film, Oxford University Press, Oxford, UK.

Snell, Bruno, 1982, The Discovery of the Mind in Greek Philosophy and Literature, Dover Publications, New York.

Strohl, Matthew, 2019, "On Culinary Authenticity", The Journal of Aesthetics and Art Criticism, vol. 77, no. 2, pp. 157-167.

a stimulating and enjoyable meeting. Finally, special thanks are due to Juan Escalona Meléndez and Sexto Colectivo for the remarkable and philosophical conference meal they prepared at the event. 
Telfer, Elizabeth, 1996, Food for Thought: Philosophy and Food, Routledge, New York.

Walton, Kendall, 2007, “Aesthetics-What? Why? and Wherefore?", The Journal of Aesthetics and Art Criticism, vol. 65, no. 2, pp. 147-161. 